\title{
PENGEMBANGAN BUDAYA BACA DI KOMUNITAS ADAT (PENYELENGGARAAN TBM DI KOMUNITAS ADAT SAMIN)
}

\author{
Febri Hartanti Purbaningrum dan Djumadi \\ e-mail: purbaningrumsinta@yahoo.com \\ PPPAUD \& DIKMAS JATENG
}

\begin{abstract}
Abstrak: Komunitas adat Samin adalah penganut ajaran Saminis merupakan sebuah komunitas yang salah satunya ada di Kabupaten Blora. Pemerintah dengan salah satu programnya tentang gerakan pemberantasan buta aksara menemukan kendala pada komunitas ini, karena sangat tertutup dan hati-hati dalam menerima hal-hal baru dari luar. Tujuan dari penelitian ini untuk mendapatkan model pengembangan budaya baca, mengetahui kelayakan dan efektivitas model pengembangan budaya baca di komunitas adat samin. Model ini menggunakan pendekatan research and development (R\&D), yang merupakan perbaikan metode yang dikembangkan oleh Borg and Gall. Metode yang digunakan meliputi metode deskriptif dan kualitatif. Penelitian ini dilaksanakan di komunitas adat Samin, Desa Sambongrejo Kecamatan Sambong Kabupaten Blora, dimulai bulan Juli - November 2016. Hasil dari penelitian ini sudah sesuai dengan uji efektivitas yang dilakukan, maka dapat disampaikan bahwa model ini efektif dan layak untuk diujicobakan secara luas pada komunitas adat. Penelitian ini juga memberikan saran mengatasi masalah yang pada intinya pengelola Taman Bacaan Masyarakat hendaknya dalam proses perencanaan, pelaksanaan, serta pelayanan terus melakukan langkah - langkah strategis agar Taman Bacaan Masyarakat dapat dikelola dengan baik.
\end{abstract}

Kata-kata kunci: komunitas adat samin, saminisme, budaya baca

\section{DEVELOPMENT OF READING CULTURE IN AN INDIGENOUS COMMUNITY (ORGANIZED BY TBM IN A SAMIN INDIGENEOUS COMMUNITY)}

\begin{abstract}
Samin indigenous community is a group of Saminist adherent located in Blora District. Government, with one of its programs-literacy movement, found obstacles in this community which is very closed and careful in accepting new things out of the community. This research aims to get reading culture development, recognize the feasibility and effectiveness of reading culture development model in that community. The model uses a research and development (R\&D) approach which is an improvement method developed by Borg and Gall. Methods used are descriptive and qualitative. This research was conducted in Samin community, Sambongrejo village, Kecamatan Sambong Blora District, starting from July to November 2016. Results of this research has been appropriate to the effectiveness test conducted, so that it can be revealed that this model is effective and feasible to be examined extensively to an indigenous community. This research also gives suggestions on how to overcome problems in which the management of community Reading Garden has to do strategic steps so that TBM can be managed well in the planning, execution, and service process.
\end{abstract}

Keywords: indigenous community of samin, saminism, reading culture

\section{PENDAHULUAN}

Indonesia merupakan negara kepulauan yang memiliki keanekaragaman etnis/suku bangsa dan budaya. Keanekaragaman ini merupakan potensi yang sangat baik untuk dikembangkan dan menjadi ciri khas tersendiri bagi bangsa Indonesia yang tidak dimiliki oleh bangsa-bangsa lain di dunia. Kondisi geografis Indonesia yang khas dan luas terdiri dari ribuan pulau baik pulau besar maupun kecil, telah 
membentuk komunitas-komunitas adat/suku yang terpencar di berbagai daerah termasuk daerahdaerah 3T (Terdepan, Terluar, dan Tertinggal). Salah satu bagian dari adat-adat tersebut adalah Komunitas Adat Terpencil (KAT) yang oleh pemerintah diberi perhatian khusus. Guna melaksanakan ketentuan Pasal 23 ayat 3 Peraturan Pemerintah Nomor 39 tahun 2012 tentang penyelenggaraan kesejahteraan sosial, Presiden Joko Widodo (Jokowi) pada tanggal 23 Desember 2014, telah menandatangani Peraturan Presiden Nomor 186 Tahun 2014 tentang Pemberdayaan Sosial terhadap Komunitas Adat Terpencil.

Salah satu kekhususan dari kondisi yang digambarkan tersebut adalah sebagaimana yang dihadapi oleh Kabupaten Blora. Pada survey yang dilakukan di Kabupaten Blora, ditemukan permasalahan tentang adanya salah satu komunitas masyarakat yang disebut wong Samin (sikep). Komunitas ini adalah penganut ajaran Saminisme. Gerakan pemberantasan buta aksara menemukan kendala pada komunitas ini, karena sangat tertutup dan hati-hati dalam menerima hal-hal baru dari luar. Pengikut ajaran Samin mempunyai lima ajaran yaitu (1) tidak bersekolah (formal); (2) tidak memakai peci, tetapi memakai "iket", yaitu semacam kain yang diikatkan di kepala mirip orang Jawa dahulu; (3) tidak berpoligami; (4) tidak memakai celana panjang dan hanya pakai celana selutut; (5) tidak berdagang dan penolakan terhadap kapitalisme (Mumfangati, 2004). Sikap dan budaya masyarakat tersebut sangat menyulitkan pemerintah daerah Kabupaten Blora ketika daerah tersebut bermaksud mendukung gerakan Bebas Buta Aksara. Oleh karena itu, diperlukan suatu alternatif upaya pembelajaran bagi komunitas masyarakat Samin/Sikep tersebut agar warga dapat membuka diri dan termotivasi untuk menjadi masyarakat yang maju tanpa meninggalkan nilai-nilai serta kearifan lokal yang dipegang selama ini.

Munculnya nilai-nilai sosial ekonomi bagi masyarakat yang ditimbulkan dari kemampuan keaksaraan ini menjadi perhatian dari pemerintah, sehingga pada tahun 2016 telah dicanangkan Gerakan Indonesia Membaca. Gerakan ini tidak akan sukses jika tidak didukung dengan kemampuan membaca dari masyarakat. Oleh karenanya, upaya pemberantasan buta aksara menjadi prioritas. Menurut Badan Pusat Statistik (BPS) tahun 2013, angka buta huruf penduduk Indonesia pada usia
15-59 berjumlah sebesar 5.984 .075 atau $3,70 \%$ dari penduduk Indonesia yang berusia 15-59 tahun. Penurunan angka buta aksara tersebut ternyata penyebarannya tidak merata, hal ini disebabkan karana kompleksnya permasalahan yang dihadapi pada masing-masing daerah. Sehubungan dengan keadaan komunitas adat Samin tersebut, Pusat Pengembangan Pendidikan Anak Usia Dini dan Pendidikan Masyarakat Jawa Tengah melakukan pengkajian dan pengembangan program Pendidikan Nonformal bermaksud mengembangkan suatu model pengembangan budaya baca pada komunitas adat Samin. Hal ini dimaksudkan sebagai salah satu langkah dalam rangka mendukung Gerakan Indonesia Membaca dan mempercepat Gerakan Tuntas Buta Aksara.

Secara teoretis, ada hubungan yang positif antara reading interest (minat baca) dengan reading habit (kebiasan membaca) dan reading ability (kemampuan membaca). Rendahnya minat baca masyarakat menjadikan kebiasaan membaca yang rendah, dan kebiasaan membaca yang rendah ini menjadikan kemampuan membaca rendah. World Bank di dalam salah satu laporan pendidikannya No. 16369-IND, "Education in Indonesia-From Crisis to Recovery" (1998) melukiskan begitu rendahnya kemampuan membaca anak - anak Indonesia. Mengutip hasil studi dari Vincent Greanary (dalam Supriyoko, 2005) dilukiskan siswa - siswa kelas enam SD Indonesia dengan nilai 51,7 ; berada di urutan paling akhir setelah Filipina $(52,6)$, Thailand $(65,1)$, Singapura $(74,0)$, dan Hongkong $(75,5)$ artinya kemampuan membaca siswa Indonesia memang paling buruk dibandingkan siswa dari negaranegara lainnya. Keadaan tersebut mengingatkan hasil penelitian yang dilakukan Supriyoko di desa - desa wilayah Sulawesi Selatan, seperti di daerah Galesong, Bantaeng, Tamalatea, dan Bisapu, yaitu dari sekitar 2.000 kasus ada 30 -an atau 1,5 persen anak lulusan SD tidak lancar membaca.

Data lain juga menyebutkan UNDP dalam Human Development Report 2000, bahwa melek huruf orang dewasa di Indonesia hanya 65,5 persen, sedangkan Malaysia sudah mencapai 86,4 persen dan negara-negara maju seperti Australia, Jepang, Inggris, Jerman dan AS umumnya sudah mencapai 99,0 persen .

Sementara itu, jumlah TBM di Jawa Tengah pada tahun ini berjumlah 777 buah. Dari jumlah itu, ada beberapa yang tidak bercitra negatif seperti 
paparan di atas. Sebagaimana hasil studi literasi yang dilakukan oleh tim peneliti PPPAUD dan Dikmas Jateng, ada beberapa TBM di Jawa Tengah yang eksistensinya benar - benar ada dan keberadaannya mendatangkan manfaat bagi masyarakat pengguna di sekitarnya. Keunggulan itulah yang menjadi salah satu alasan pemilihan lokasi pelaksanaan program unggulan pendidikan nonformal ini.

Berdasarkan uraian di atas, nampak bahwa penyelenggaraan program ini tidak sekedar mengurangi jumlah penyandang buta aksara, akan tetapi jauh lebih substansial yaitu agar melalui kemampuan tersebut seseorang dapat memanfaatkannya dalam praktik kehidupan sehari-hari sesuai dengan tuntutan peran sosial yang disandang. Maknanya bahwa kemampuan keaksaraan (baca, tulis, hitung) hanyalah sebagai alat atau instrumen. Kemampuan keaksaraan tersebut sekedar bekal atau modal bagi seseorang yang bisa dan perlu dimanfaatkan sefungsional mungkin dalam kehidupan sehari-hari. Pendidikan keaksaraan bagi orang dewasa lazim disebut sebagai pendidikan dasar bagi orang dewasa, oleh karenanya, pendidikan keaksaran ini diasumsikan mempunyai sifat instrumental dalam rangka perbaikan sosial dan ekonomi. Kemampuan baca tulis tidaklah bermakna dalam dirinya, tetapi kebermaknaannya terletak pada dampak perbaikan sosial ekonomi yang ditimbulkannya.

Berdasarkan latar belakang tersebut di atas, permasalahan yang diteliti adalah bagaimana model Pengembangan Budaya Baca di komunitas adat Samin? Apakah model tersebut layak digunakan di komunitas adat? dan bagaimana keefektifan model tersebut? sedangkan manfaat dari penelitian ini adalah secara praktis, model ini dapat dijadikan acuan bagi masyarakat yang ingin mengembangkan model pengembangan budaya baca pada komunitas adat, dan secara konseptual, model ini dapat menjadi penentu kebijakan dalam rangka mengembangkan model pengembangan budaya baca pada komunitas adat.

\section{METODE PENELITIAN}

Berdasarkan pendapat dari beberapa pakar bidang penelitian dan pengembangan, tahapan dalam proses pengembangan produk disebut sebagai siklus yang terdiri atas kegiatan (1) pengkajian temuan penelitian yang berkaitan dengan produk yang dikembangkan, (2) pengembangan produk berdasarkan temuan penelitian, (3) uji coba lapangan tempat produk itu akan digunakan, dan (4) revisi produk untuk mengoreksi kelemahan yang ditemukan di dalam tahapan uji coba lapangan.

Model ini menggunakan pendekatan research and development (R\&D). Metode ini merupakan perbaikan metode yang dikembangkan dari Borg and Gall (1983). Alasan penggunaan pendekatan tersebut adalah karena dalam pendekatan itu terdapat suatu rangkaian proses penelitian yang hasilnya dapat digunakan untuk mengembangkan dan memvalidasi produk pendidikan.

Borg dan Gall (1983) menyatakan bahwa prosedur penelitian dan pengembangan mencakup sepuluh tahapan, yaitu (1) penelitian dan pengumpulan informasi, (2) perencanaan, (3) pengembangan bentuk produk awal, (4) uji coba lapangan pendahuluan, (5) revisi produk utama. (6) uji coba lapangan utama, (7) revisi produk operasional, (8) uji lapangan operasional, (9) revisi produk akhir, serta (10) diseminasi dan implementasi. Merujuk pada tahapan penelitian dan pengembangan sebagaimana yang disarankan oleh Borg dan Gall tersebut, maka kegiatan - kegiatan yang dilakukan dalam penelitian ini mencakup (1) studi eksplorasi, (2) review literatur, (3) pengembangan model, (4) evaluasi model, (5) uji coba model, (6) analisis, serta (7) revisi produk akhir dan diseminasi.

Metode yang digunakan meliputi metode deskriptif dan kualitatif. Metode deskriptif dipergunakan untuk menghimpun kondisi yang ada di lapangan. Metode kualitatif dipergunakan untuk menilai kualitas dari kelayakan model pengembangan budaya baca di komunitas adat. Melalui metode ini diharapkan dapat diperoleh masukan tentang kelebihan - kelebihan dan kekurangan-kekurangan dari produk yang dikembangkan.

\section{Lokasi dan Subjek Penelitian}

Kegiatan pengembangan model pengelolaan taman bacaan masyarakat pada komunitas adat ini mengambil tempat di Desa Sambongrejo, Kecamatan Sambong, Kabupaten Blora dengan beberapa persyaratan yang harus dipenuhi, antara lain mempunyai tempat pembelajaran teori yang representatif, mempunyai tempat pembelajaran praktik yang layak sesuai standar, dan memiliki 
lembaga mitra.

Kegiatan pengembangan dibagi menjadi tiga bagian, yaitu sosialisasi, pelaksanaan, dan pemanfaatan taman bacaan masyarakat, serta peningkatan budaya baca komunitas adat Samin. Subjek penelitian untuk pengembangan dan uji coba model adalah komunitas adat Samin di Desa Sambongrejo, Kecamatan Sambong, Kabupaten Blora. Penetapan subjek penelitian ini didasarkan pada tiga pertimbangan pokok, yaitu (1) telah melaksanakan berbagai program pendidikan keaksaraan; (2) penyelenggara memiliki keinginan untuk mengembangkan model yang relevan dengan kebijakan pemerintah dan kebutuhan masyarakat; dan (3) berdasarkan kajian studi eksplorasi tim pengembang komunitas adat samin di Desa Sambongrejo, Kecamatan Sambong, Kabupaten Blora memungkinkan untuk dikembangkan lebih lanjut tentang penerapan model pengembangan budaya baca pada komunitas adat.

Desain penelitian yang digunakan dalam penelitian ini adalah one group pre-test post-test design. Dalam desain ini, sebelum perlakuan diberikan terlebih dahulu sampel diberi pre-test (tes awal) dan di akhir program sampel diberi post-test (tes akhir). Desain ini digunakan sesuai dengan tujuan yang hendak dicapai yaitu ingin mengetahui peningkatan budaya baca di komunitas adat samin setelah diselenggarakan TBM di komunitas adat samin tersebut.

Penerapan uji coba komunitas adat samin di Desa Sambongrejo, Kecamatan Sambong, Kabupaten Blora ini dilakukan pada peserta didik 20 orang dengan kriteria yang sudah ditetapkan. Sasaran pelaksana model adalah tim pengelola di komunitas adat samin di Desa Sambongrejo, Kecamatan Sambong, Kabupaten Blora, dan disesuaikan dengan kebutuhan model yang akan dikembangkan.

\section{Teknik Pengumpulan Data}

Metode pengumpulan data digunakan untuk menghimpun data tentang penerapan model pengembangan budaya baca pada komunitas adat. Teknik pengumpulan data dalam penelitian ini menggunakan kuesioner, wawancara, obervasi, focus group discussion, teknik delphi, dan metode dokumentasi.

Kuesioner digunakan untuk mengukur minat baca peserta didik dan tingkat kepuasan pengguna (users) dan fasilitas yang disediakan untuk mendukung minat baca serta manfaat yang diperoleh. Data yang diperlukan dalam penelitian kuantitatif harus berupa angka agar dapat dianalisis secara statistik. Untuk mendapatkan data yang terukur, diperlukan instrumen penelitian berupa angket yang dapat mengungkap variabel penelitian. Kuesioner sebagai alat pengumpulan data dapat mengungkap fakta menurut pengalaman responden berdasarkan pertanyaan/pernyataan penelitian yang dapat dikuantifikasi untuk kepentingan analisis data kuantitatif (Sugiyono, 1999).

Wawancara adalah suatu percakapan secara tatap muka (bertemu langsung dengan yang diwawancarai) dengan memiliki tujuan tertentu (Lincoln dan Guba, 1995). Tim pengembang melakukan wawancara dengan tutor, tokoh masyarakat, penyelenggara, TLD/FDI, Pengelola dan juga peserta didik. Melalui wawancara, tim pengembang melakukan tahap-tahap, yaitu (1) persiapan wawancara, (2) menentukan siapa yang diwawancarai, (3) melaksanakan wawancara, dan (4) mendeskripsikan hasil wawancara.

Observasi sebagai teknik ilmiah dilakukan dengan pengamatan dengan pencatatan secara sistematis terhadap fenomena atau kejadian yang diselidiki. Observasi terutama ditujuakan untuk memperoleh data yang berhubungan dengan apa yang dikerjakan (cultural behaviour) dan apa yang diperbuat dan dipergunakan (cultural artifacts) oleh partisipan (Lincoln dan Guba, 1985). Dalam melakukan observasi, pengembang dapat menetapkan diri sebagai partisipan atau nonpartisipan atau dapat melakukan secara terus terang atau sembunyi-sembunyi.

Focus gorup discussion (FGD) digunakan untuk mengumpulkan data berkenaan dengan validasi konseptual dengan cara mendiskusikan draf awal model pengembangan budaya baca pada komunitas adat. Peserta focus group discussion adalah orang - orang yang memiliki kemampuan dan keahlian dalam bidang pendidikan keaksaraan, taman bacaan masyarakat sehingga mampu memberikan sumbangan pemikiran.

Focus group discussion dilakukan dengan curah pendapat. Tiap peserta bebas menyampaikan ide - idenya tentang proses pengembangan budaya baca pada komunitas adat dan indikator-indikator yang dikembangkan berupa saran dan usul perbaikan dan penambahan model yang dirumuskan.

Teknik delphi yang digunakan dalam 
penelitian ini merupakan suatu cara sistematis untuk memperoleh kesepakatan pendapat (konsensus) mengenai rancangan kuesioner (rumusan kompetensi dan indikatornya) kepada praktisi lewat saling tukar pendapat dan mengembangkan ide. Praktisi diminta pendapatnya dengan cara memberikan respon pernyataan untuk saran dan perbaikan dari model yang dirumuskan.
Dokumentasi digunakan untuk mengumpulkan data dari sumber noninsani yang berupa dokumen dan rekaman. Dokumen dan rekaman merupakan sumber informasi yang stabil, akurat untuk merefleksikan situasi yang terjadi di masa lampau. Teknik ini sebagai pelengkap dari teknik yang lainnya.

\section{HASIL DAN PEMBAHASAN}

Sedulur Sikep dari bahasa Jawa berarti "Sahabat Sikep" adalah kelompok masyarakat yang berusaha menjalankan kehidupan sehari - hari sesuai dengan ajaran Samin. Komunitas masyarakat yang disebut Sedulur Sikep ini terbanyak ditemukan di daerah Blitar, Madiun, Provinsi Jawa Timur dan di daerah Pati, Rembang Blora yang ada di Provinsi Jawa Tengah. Ajaran ini (semenjak kematian tokoh penyebarnya Samin tahun 1914 dalam pengasingan di kota Padang Sumatera Barat) kaum 'Sedulur Sikep' sudah mulai beradaptasi dengan perubahan zaman dan tidak terlalu kaku dalam menjalankan konsep murni ajaran tersebut. Namun terdapat juga segolongan masyarakat Sikep yang menentang pembaruan dan menuntut dijalankannya kembali ajaran Samin secara murni. Pengikut ajaran Samin mempunyai lima ajaran, yaitu tidak bersekolah, tidak memakai peci tetapi memakai iket semacam kain yang diikatkan di kepala mirip orang Jawa jaman dahulu, tidak berpoligami, tidak memakai celana panjang atau hanya memakai celana selutut, serta menolak kapitalisme.

Sebagaimana paham lain yang dianggap oleh pendukungnya sebagai agama, orang Samin juga memiliki "kitab suci". "Kitab suci"' itu adalah Serat Jamus Kalimasada yang terdiri atas beberapa buku, antara lain Serat Punjer Kawitan, Serat Pikukuh Kasajaten, Serat Uri-uri Pambudi, Serat Jati Sawit, Serat Lampahing Urip, dan merupakan nama nama kitab yang amat populer dan dimuliakan oleh orang Samin. Walaupun masa penjajahan Belanda dan Jepang telah berakhir, orang Samin tetap menilai pemerintah Indonesia saat itu tidak jujur. Oleh karenanya, ketika menikah tidak mencatatkan dirinya baik di Kantor Urusan Agama/(KUA) atau di catatan sipil.

Secara umum, perilaku orang Samin/ 'Sikep' sangat jujur dan polos tetapi kritis. Penampilan orang Samin berpakaian baju lengan panjang tanpa kerah serta berwarna hitam. Laki - laki memakai ikat kepala, wanita memakai kebaya lengan panjang, berkain sebatas di bawah tempurung lutut atau di atas mata kaki. Hubungan ketenagaan baik sesama Samin maupun masyarakat di luar Samin terjalin dengan baik. Dalam menjaga dan melestarikan hubungan kekerabatan, masyarakat Samin memiliki tradisi untuk saling berkunjung terutama pada saat satu keluarga mempunyai hajat sekalipun tempat tinggalnya jauh.

Hasil dari penelitian sebelumnya adalah adanya gejala enggan membaca telah menggerogoti para penduduk dan para pelajar saat ini. Kepala Perpustakaan Nasional, Dady P Rachmananta (2003) pada konferensi pers dalam rangka Hari Aksara Nasional (HAN) (dalam Hardianto, 2011) mengungkapkan kalangan berpendidikan tinggi seperti mahasiswa memiliki minat membaca yang relatif rendah. Masih banyak pelajar yang bisa lulus tanpa sekalipun pernah ke perpustakaan.

Penerapan model pengembangan budaya baca pada komunitas adat, telah diterapkan sesuai dengan prosedur yang ditetapkan meliputi ketepatan judul, kebermanfaatan, kesesuaian isi dengan judul, komposisi model, bahasa dan kalimat sesuai EYD. Berdasarkan uraian masing-masing komponen tersebut, di bawah ini disajikan hasil validasi model pembelajaran yang diperoleh dari 20 responden.

Berdasarkan masukan dari responden, diperoleh tiga masukan penting dalam Model Pengembangan Budaya Baca Pada Komunitas Adat, yaitu (1) terlalu banyak narasi, sehingga perlu untuk dipersingkat, lebih banyak inti yang dikemukakan; (2) perlu ada variasi penulisan huruf (tebal, tipis, penulisan miring, disesuaikan dengan kaidah penulisan ilmiah); serta (3) cover diperbaiki, diberi contoh gambar orang yang sedang melakukan aktivitas membaca dengan latar belakang dan pakaian adat samin. 


\section{Penyusunan Perangkat Pendukung Model}

Panduan Pengelolaan Taman Bacaan

Masyarakat Komunitas Samin disusun untuk mendukung proses pengembangan budaya baca, sehingga ketentuan-ketentuan yang belum terdapat pada model dapat merujuk pada panduan - panduan. Unsur penilaian pada panduan pengelolaan ini meliputi isi dan bahasa yang terdiri dari tulisan naskah, kebermanfaatan, tingkat kesulitan materi, relevansi naskah, gambar-gambar, dan kesesuaian EYD. Bagian layout yang dinilai meliputi tampilan naskah, tampilan huruf/jenis huruf, bentuk dan ukuran huruf, serta tata letak. Berdasarkan uraian tersebut, maka hasil validasi terhadap panduan pengelolaan taman bacaan masyarakat komunitas adat adalah (1) panduan hendaknya berisi petunjuk singkat tahap demi tahap yang harus dilakukan oleh pembaca terhadap produk yang akan dipakai, (2) bahasa yang digunakan lebih operasional sehingga lebih mudah dipahami (menggunakan kalimat yang efektif), (3) tata letak dan penempatan gambar untuk memperjelas keterangan dibuat lebih baik lagi; serta (4) hendaknya menggunakan gambar atau bagan yang mudah dipahami oleh pembaca

Panduan Pengadaan Bahan Bacaan Taman Bacaan Masyarakat Komunitas Adat disusun untuk mendukung model, sehingga ketentuanketentuan yang belum terdapat pada model dapat merujuk pada panduan. Unsur penilaian pada panduan pengadaan bahan bacaan ini meliputi isi dan bahasa yang terdiri dari tulisan naskah, kebermanfaatan, relevansi naskah, gambar-gambar, dan kesesuaian EYD. Bagian layout yang dinilai meliputi tampilan naskah, tampilan huruf/jenis huruf, bentuk dan ukuran huruf, dan tata letak. Berdasarkan uraian tersebut, maka hasil validasi terhadap panduan pengadaan bahan bacaan adalah (1) panduan berisi petunjuk operasional pengadaan bahan bacaan taman bacaan masyarakat, (2) isi bacan sesuai dengan judul yang ditawarkan, (3) tata letak dan penempatan gambar mampu memberikan keterangan dari isi bacaan yang disampaikan, serta (4) gambar-gambar yang disertakan ditambah untuk meningkatkan pemahaman pembaca terhadap panduan yang dibacanya.

Panduan Bentuk Layanan Taman Bacaan Masyarakat disusun untuk mendukung proses pengelolaan, sehingga ketentuan-ketentuan yang belum terdapat pada model dapat merujuk pada panduan ini. Unsur penilaian pada panduan ini meliputi isi dan bahasa yang terdiri dari tulisan naskah, kebermanfaatan, relevansi naskah, gambargambar, dan kesesuaian EYD. Bagian layout yang dinilai meliputi tampilan naskah, tampilan huruf/jenis huruf, bentuk dan ukuran huruf, serta tata letak. Berdasarkan uraian tersebut, maka hasil validasi terhadap panduan bentuk layanan taman bacaan masyarakat adalah (1) panduan berisi petunjuk singkat, memuat tahap demi tahap yang harus dilakukan oleh pembaca terhadap produk yang akan dipakai, (2) bahasa yang digunakan disusun secara baik dan mudah dipahami oleh pembaca, (3) tata letak dan penempatan gambar mampu menjelaskan keterangan yang disampaikan melalui tulisan, serta (4) perlu ditambahkan bagan-bagan untuk keterangan yang berupa langkah yang harus dilakukan oleh pembaca.

Panduan Penyelenggaraan Taman bacaan Masyarakat Komunitas Adat disusun untuk mendukung model, sehingga proses penerapan model dapat berjalan dengan lebih baik, serta membantu pengelola dalam melayani pelanggan. Unsur penilaian pada panduan ini meliputi isi dan bahasa yang terdiri dari tulisan naskah, kebermanfaatan, relevansi naskah, gambargambar, dan kesesuaian EYD. Bagian layout yang dinilai meliputi tampilan naskah, tampilan huruf/ jenis huruf, bentuk dan ukuran huruf, serta tata letak. Berdasarkan uraian tersebut, maka hasil validasi terhadap panduan ini adalah (1) bahasa yang disusun sudah cukup baik, (2) ilustrasi yang disampaikan mampu memberikan penjelasan tambahan dari keterangan yang disampaikan, (3) perlu dipersingkat, sehingga panduan hanya memuat yang pokok - pokok saja yang harus dikuasai oleh pembaca, serta (4) proporsi tulisan dan gambar sudah bagus dan tingkat keterbacaan lebih baik.

Panduan Pengelolaan Sarana dan Prasarana bagi TBM Komunitas Adat disusun untuk mendukung proses pengelolaan, sehingga penerapan model dapat berjalan dengan lebih baik, serta membantu pengelola dalam melayani pelanggan. Unsur penilaian pada panduan ini meliputi isi dan bahasa yang terdiri dari tulisan naskah, kebermanfaatan, relevansi naskah, gambargambar, dan kesesuaian EYD. Bagian layout yang dinilai meliputi tampilan naskah, tampilan huruf/jenis huruf, bentuk dan ukuran huruf, serta tata letak. Berdasarkan uraian tersebut, maka hasil validasi terhadap panduan ini adalah (1) panduan hendaknya 
lebih singkat serta memuat setiap tahapan kegiatan secara runtut, (2) bahasa yang digunakan lebih operasional sehingga lebih mudah dipahami, (3) tata letak dan penempatan gambar untuk memperjelas keterangan dibuat lebih baik lagi, serta (4) jenis huruf yang digunakan tidak terlalu bervariasi.

Bahan Ajar Pendidikan KeaksaraanJudul Biogas disusun untuk mendukung proses pembelajaran, sehingga proses pembelajaran dapat berjalan dengan lebih baik, serta membantu tutor dalam penyampaian materi. Unsur penilaian pada bahan ajar ini meliputi isi dan bahasa yang terdiri dari tulisan naskah, kebermanfaatan, tingkat kesulitan materi, relevansi naskah, gambar - gambar, dan kesesuaian EYD. Bagian layout yang dinilai meliputi tampilan naskah, tampilan huruf/jenis huruf, bentuk dan ukuran huruf, serta tat letak. Berdasarkan uraian tersebut, maka hasil validasi terhadap bahan ajar ini adalah (1) menggunakan bahasa yang sederhana, (2) gambar-gambar menggunakan gambar kegiatan komunitas adat, serta (3) tata letak bahan ajar dibuat lebih baik lagi.

Bahan Ajar Beternak Kambing disusun untuk mendukung proses pembelajaran, sehingga proses pembelajaran dapat berjalan dengan lebih baik, serta membantu tutor dalam penyampaian materi. Unsur penilaian pada bahan ajar ini meliputi isi dan bahasa yang terdiri dari tulisan naskah, kebermanfaatan, tingkat kesulitan materi, relevansi naskah, gambar - gambar, dan kesesuaian EYD. Bagian layout yang dinilai meliputi tampilan naskah, tampilan huruf/jenis huruf, bentuk dan ukuran huruf, serta tata letak. Berdasarkan uraian tersebut, maka hasil validasi terhadap bahan ajar ini adalah (1) bahan ajar hendaknya berisi bacaan yang menarik bagi komunitas adat, (2) gambar-gambar yang disertakan hendaknya mengambil gambar dari komunitas adat setempat, (3) tata letak dan penempatan gambar untuk memperjelas keterangan dibuat lebih baik lagi, serta (4) materi yang disajikan lebih singkat namun mencakup keseluruhan dan disusun dalam kalimat sederhana agar menarik pembaca.

Panduan Kemitraan dan Kerjasama di TBM

Komunitas Adat disusun untuk mendukung model, sehingga proses penerapan model dapat berjalan dengan lebih baik, serta membantu pengelola dalam melayani pelanggan. Unsur penilaian pada panduan ini meliputi, isi dan bahasa yang terdiri dari tulisan naskah, kebermanfaatan, relevansi naskah, gambar - gambar, dan kesesuaian EYD. Bagian layout yang dinilai meliputi tampilan naskah, tampilan huruf/jenis huruf, bentuk dan ukuran huruf, serta tata letak. Berdasarkan uraian tersebut, maka hasil validasi terhadap panduan ini adalah (1) hendaknya menggunakan kalimat efektif, (2) menggunakan kalimat operasional yang mudah dipahami pembaca, serta (3) berikan bagan-bagan pada setiap langkah yang disarankan untuk mempermudah pemahaman pembaca.

Poster Ayo Membaca 1 disusun untuk mendukung model, sehingga proses penerapan model dapat berjalan dengan lebih baik, serta membantu pengelola dalam pelayanan pelanggan. Unsur penilaian pada poster ini meliputi isi dan bahasa yang terdiri dari tulisan naskah, kebermanfaatan, relevansi naskah, gambar-gambar, dan kesesuaian EYD. Bagian layout yang dinilai meliputi tampilan naskah, tampilan huruf/jenis huruf, bentuk dan ukuran huruf, serta tata letak. Berdasarkan uraian tersebut, maka hasil validasi terhadap poster ini adalah (1) kalimat / kata yang digunakan singkat, padat, jelas, dan memotivasi pembaca; serta (2) gambar dikurangi, cukup dua gambar yang menunjukkan aktivitas membaca pada komunitas adat.

Poster Ayo Membaca 2 disusun untuk mendukung proses pembelajaran, sehingga proses penerapan model dapat berjalan dengan lebih baik, serta membantu pengelola dalam pelayanan pelanggan. Unsur penilaian pada poster ini meliputi isi dan bahasa yang terdiri dari tulisan naskah, kebermanfaatan, relevansi naskah, gambargambar, dan kesesuaian EYD. Bagian layout yang dinilai meliputi tampilan naskah, tampilan huruf/ jenis huruf, bentuk dan ukuran huruf, serta tata letak. Berdasarkan uraian tersebut, maka hasil validasi terhadap poster ini adalah (1) gambar dibuat lebih jelas, (2) menunjukkan aktivitas dan motivasi membaca, (3) penempatan gambar tidak mengganggu ejaan membaca, dan (4) gambar hendaknya menunjukkan identitas komunitas adat sedang beraktivitas membaca. 


\section{PENUTUP}

\section{Kesimpulan}

Berdasarkan hasil penelitian, pengembangan dan pembahasan yang telah disajikan, dapat disimpulkan bahwa proses penerapan model pengembangan budaya baca pada komunitas adat melalui penyelenggaraan taman bacaan masyarakat pada komunitas Samin dapat berjalan dengan baik sesuai dengan jadwal waktu yang telah ditetapkan dalam kegiatan uji coba pengembangan model pada tim pengembangan dari kelompok kerja pendidikan masyarakat. Proses pengembangan ini mampu memberikan data dan informasi tentang keefektifan model yang disusun beserta perangkat - perangkat model yang terkait, berupa model, panduan - panduan, dan bahan ajar pendukung serta produk pengembangan lainnya. Melalui serangkaian uji coba ini diperoleh sejumlah data dan informasi terkait dengan pengembangan budaya baca yang harus diterapkan pada komunitas adat yang sesuai dengan kebutuhan masyarakat dan dunia pendidikan melalui penerapan model ini. Pada prosesnya, kegiatan uji coba dan pengembangan model ini membuka cakrawala tentang data dan informasi sasaran, kebutuhan dan strategi peningkatan budaya baca pada komunitas adat agar masyarakat pada komunitas adat mempunyai kemampuan yang memadai dalam pengembangan kehidupannya. Proses penerapan model yang dilaksanakan pada uji coba dan pengembangan model ini menggambarkan suasana pengelolaan taman bacaan masyarakat yang mendekati pada pemenuhan kebutuhan masyarakat komunitas adat, sehingga mampu memberikan informasi pada pihak terkait dalam menentukan kriteria taman bacaan masyarakat yang tepat untuk meningkatkan budaya baca pada komunitas adat samin. Sebagai bagian akhir dari kesimpulan ini dapat disampaikan bahwa kegiatan pengembangan dan ujicoba model ini telah dilaksanakan dengan baik oleh tim pengembangan dari kelompok kerja Pendidikan Masyarakat dan melibatkan unsur terkait. Sesuai dengan uji efektivitas yang dilakukan, maka dapat disampaikan bahwa model ini efektif dan layak untuk diujicobakan secara luas pada komunitas adat.

\section{Saran}

Berdasarkan analisis, pembahasan dan kesimpulan, ada beberapa saran yang disampaikan kepada pihak - pihak yang terkait dengan penyelenggaraan pengembangan budaya baca pada komunitas adat Samin, bahwa pengelola yang ditunjuk dalam pengelolaan taman bacaan masyarakat komunitas adat hendaknya lebih baik lagi dalam setiap proses yang hendak dilaksanakan ini, mulai dari perencanaan, pelaksanaan, dan pelayanan. Pengelola hendaknya terus melakukan langkah - langkah strategis yang dapat mendukung terlaksananya pengelolaan TBM di lingkungannya, dan pemerintah daerah hendaknya turut serta membantu dalam prosesnya, melalui program monitoring bagi lembaga-lembaga yang menjadi binaannya, serta jajaran Ditjen PAUD dan DIKMAS hendaknya melakukan sosialisasi terhadap inovasi yang dilakukan oleh para pelaku pendidikan di lapangan melalui media-media yang dimiliki, seperti jurnal ilmiah, acara-acara seremonial dan lainnya yang dapat menggugah motivasi masyarakat pada umumnya dan pelaku pendidikan non formal khususnya untuk selalu dan terus berinovasi menciptakan model-model baru dalam pendidikan non formal. Unit-unit usaha dan industri hendaknya memberikan perhatian sungguh-sungguh pada penyelenggaraan TBM pada komunitas samin ini, sehingga mampu mendukung peningkatan kemandirian dan budaya baca pada masyarakat secara luas.

\section{DAFTAR PUSTAKA}

Badan Pusat Statistik. (2013. Data jumlah penduduk Indonesia tahun 2013. Badan Pusat Statistik. Jakarta.

Borg, W.R \& Gall, M.D. (1983). Educational Research: An Introduction (4thEdition). New York: Longman.
Hardianto, D. (2011). Studi tentang minat baca mahasiswa Fakultas IImu Pendidikan UNY. Majalah IImiah Pembelajaran, 7(1), 109

Lincoln, Y.S \& Guba, E.G.(1995). Naturalistic inguiry. Beverly Hills: Sage Publication Inc.

Mumfangati, T. (2004). Kearifan lokal di lingkungan 
masyarakat Samin Kab. Blora Jateng. Yogyakarta: Jarahnitra.

Peraturan Pemerintah Republik Indonesia Nomor 39 tahun 2012 tentang Penyelenggaraan kesejahteraan sosial.

Sugiyono. (1999). Metode penelitian bisnis. Cetakan ke-6.Bandung: CV. Alfa Beta.
Supriyoko, K. (2005). Minat baca dan kualitas bangsa. Diakses dari http://smp.alkausar.org/ detail/artikel.php?id=118

UNDP. (2000). Human development report 2000. New York: United Nations Publications. Diakses dari http://www.undp.org/hdro. 